\title{
The Factors Affecting Green Supply Chains: Empirical Study of Agricultural Chains in Vietnam
}

\author{
Thị Mai Yến Phạm ${ }^{1} \&$ Thị Minh Khuyên Phạm ${ }^{1}$ \\ ${ }^{1}$ Thái Nguyên University of Technology, Thai Nguyen city, Vietnam \\ Correspondence: Thị Mai Yến Phạm, Thái Nguyên University of Technology, Thai Nguyen city, Vietnam. \\ E-mail: yen.phammai@tnut.edu.vn or khuyenqlen@gmail.com
}

Received: March 15, 2017

Accepted: April 3, 2017 Online Published: May 29, 2017

doi:10.5539/jms.v7n2p135

URL: http://doi.org/10.5539/jms.v7n2p135

\begin{abstract}
This paper aims at identifying the factors affecting green supply chain in agriculture in Vietnam currently. The literature indicates 14 factors affecting green supply chains in agriculture including: (i) manager commitment, (ii) IT system, (iii) new technology, (iv) organizational culture, (v) HR quality, (vi) energy \& waste management, (vii) market \& competition, (viii) political supports, (ix) knowledge \& experience, (x) actors' participation, (xi) costs, (xii) suppliers, (xiii) logistics management, and (xiv) consumer awareness. Our regression model with 14 independent variables was established to determine the factors affecting the success of green supply chains in Vietnam agriculture. The regression results show six factors affecting significantly and positively green supply chain in agriculture in Vietnam, including: (i) manager commitment, (ii) new technology, (iii) HR quality, (iv) knowledge \& experience, (v) logistic management, and (vi) consumer awareness. Hence, the paper suggests some recommendations to Vietnam firms and State for improving green supply chain in agriculture.
\end{abstract}

Keywords: supply chain, green supply chain, agriculture, firm, Vietnam

\section{Introduction}

A supply chain is the sequence of processes involved in the production and distribution of a product, with the participation of organizations and individuals for changing materials into products and delivering to consumers through transport services (Tomohiro, 2011). Since 1990, manufacturers have had to be confronted with the pressure to solve the environmental issues in their supply chains so as to reduce to a minimum the environmental impacts of a product or service. Green supply chains were created and developed widely in most developing countries and then spread out into the surrounding areas. The 2009 survey results on 13.000 in more than 17 Asian countries by Global Intelligence Alliance Group (GIA - a market consultant) indicate that consumers are willing to spend more on green products. Specially, in Japan, $70 \%$ of consumers are willing to accept $5 \%$ higher prices; that of Australia is 57\% and Singapore 55\%. Also, under GIA's survey, the stringent regulations of some countries like Europe, United States of America, on the restriction of hazardous substances promote the development of green supply chains.

Green supply chain plays an important role in the world's economy currently, especially in agriculture. In addition, consumers' health has received much more attention by managing the contents of hazards substances and agricultural by-products. Vietnam is a country in which agriculture makes up a high proportion and its agricultural products for export are expanding to European countries where the product quality requirements are rather stringent. Joining the tendency towards applying green supply chain, Vietnam is attaching special importance to develop green supply chains in agriculture to improve the competitive capacity of its agricultural products in the world market.

According to the Vietnam Ministry of Agriculture and Rural Development, as of November 2016, 50 Vietnam provinces and cities apply the model of safe food supply chain with a total of 144 chains (144 chains were granted certificates). Nevertheless, as assessed by the economic experts, Vietnam's agricultural products have less competitiveness compared to those of other countries in the global market. Also, the links among participants in Vietnam green supply chains are weak due to the numerous factors affecting green supply chain in agriculture.

For the reasons above, we decided to study the subject that focuses on "The factors affecting green supply chains: empirical study of agricultural chains in Vietnam". This research aims to assess the current situation of Vietnam 
green supply chains in agriculture and the factors affecting Vietnam supply chains. Hence, we suggest some recommendations to firms in agricultural chains and Vietnam State for improving the green supply chains in the coming time.

\section{Theoretical Framework}

Green supply chain is the sequence of processes involved in the materials management, production and distribution of a product by applying advanced technology for minimizing environmental damage throughout the process. Also, green supply chain contributes to creating firms' sustainable value based on the balance between economic performance and environmental protection (Dashore \& Sohani, 2013).

In the early period of green supply chain application, there were five main factors for assessing supply chain performance, including: green design, green operations, reverse logistics, waste management, and green manufacturing (Scupola, 2003). However, the nature of green supply chain has now been changed by some factors. In general, green supply chain involves in the following four factors:

Firstly, green purchasing: Using the raw materials that have little negative impacts on human health and living environment; appreciating energy-saving materials and reusable products.

Secondly, green manufacturing/ materials management: Firms develop a green manufacturing system by using necessary resources, cycling waste, minimizing industrial flue gases. Or firms can manufacture environmentally friendly "green" products, particularly products used in renewable energy systems.

Thirdly, green distribution: This factor involves in building, carrying out modes of transport to carry goods throughout the circulation process, from purchasing to manufacturing, distributing and reusing. Priority is given to selecting the modes of transport that have little impacts on the socio-ecological environment.

Fourthly, reverse logistics: Putting together steps in planning, carrying out and controlling the circulation process of raw materials, semi-finished products and relevant information from points of sale back to the starting point with the aim of recovering of values and taking appropriate measures to handle defective products, reused products...

Effective appliance of green supply chains to the economy in general and to corporate activities in particular will yield numerous economic benefits for the participants. Firms will improve their product quality, creating sustainable values as well as reducing the economy's environmental impacts, especially during the period the global economy is being seriously affected by climate change (Sanjay, 2010).

Green supply chains have widely been applied and brought into play their performance in all sectors, including agriculture. Basically, green supply chains in agriculture involve all the fundamental factors of a green supply chain and the specific features of the agricultural sector (Singh, 2012). Green supply chains in agriculture are mainly concentrated in safe agricultural product supply chains, starting from manufacturing under standard models to storing, circulating and transferring to the hands of consumers.

In green supply chains in agriculture, there is the participation of individuals, cooperatives, distributors and flows of materials, raw materials, finished products to the hands of end-users. Green supply chains in agriculture are a collection of activities of manufacturing, transferring quality agricultural products to best meet market needs. In each line, each type of product, one or more supply chains can be applied at the same time, depending on the particular characteristics of manufacturing and consumer market. Specifically, in the coffee industry, firms can participate in green supply chains of domestic product consumption (through the system of retail trading, agent distribution, supermarkets, etc.) or set up their own green supply chains to export coffee products to the European markets or other regions. Standing out in relief in the agricultural sector against the general global economy at present are safe agricultural product supply chains which have been being widely established and applied by manufacturers, providers. The aim of developing, expanding agricultural supply chains is establishing a human health safety and environmentally friendly agricultural product supply system.

Safe agricultural product green supply chains allow minimizing food unsafety, avoiding overuse of plant protection drugs, prohibited substances, antibiotics in husbandry, aquatic and sea products to meet retailers' requirements and strict agricultural product import regulations of developed countries (Sixiao, 2011). However, the implementation of green supply chains in agriculture at present is under the impact of numerous factors which reduces the chain competitive capacity and integration.

On the basis of literature review, we establish the following 14 factors that affect green supply chains in agriculture:

H1: Manager commitment has a positive impact on green supply chain's success (Manager commitment). 
Manager commitment creates a unity in the method of managing chain green activities, reduce contradictions in the green supply chain operating process. Restrictions of green supply chain management capacity affect the whole chain success, and the most profound impacts may be the loss of the entire green agricultural product quality improvement performance, the destruction of chain integration (Sunil, 2010).

H2: Information technology system has a positive impact on green supply chain's success (IT system). IT applications to green supply chains in agriculture, through the computer system jointly installed with application software, enable participants in the supply chains to exchange easily, to update information on time, to create a more steadfast integration between the chain intermediate steps (Shreejith, 2012). Hence, information system integration plays a really important role in green supply chains in agriculture.

H3: New technology has a positive impact on green supply chain's success (New technology). The application of modern science and technology to chain allows improving green supply chain's performance. Especially, in countries where special importance is attached to agricultural development, in order to facilitate good green supply chain activities, the application of advanced technology and engineering should be actively strengthened to improve productive capacity, minimize direct environmental effects, and reduce the use of various kinds of stimulants hazardous to human health (Kamolkittiwong \& Phruksaphanrat, 2015).

H4: Effective organizational culture has a positive impact on green supply chain's success (Organizational culture). Organizational culture heavily depends on chain managers' human resource management (Kamolkittiwong \& Phruksaphanrat, 2015). If organizational culture is effectively carried out by firms, it contributes to improving work quality and the performance of green supply chains in agriculture as well.

H5: High HR quality has a positive impact on green supply chain's success (HR quality). High-quality human resources involve employees with prominent skills and preeminent thinking. This factor determines supply chains' the productivity and competitive capacity.

H6: Effective energy and waste management has a positive impact on green supply chain's success (Energy \& waste management). This factor has a profound impact on the implementation performance of green supply chains in agriculture, proceeding from the main goal of the chains, i.e. to reduce environmental effects to a minimum, save and use resources efficiently and effectively, as well as reuse or take measures to treat waste in a safe manner.

H7: Changing and competitive market and competition have a negative impact on green supply chain's success (Market \& Competition). This is the factor encountered by any supply chain, due to the constant shifting of customer requirements and the ability to satisfy of firms (Mudgal et al., 2010). Green supply chains in agriculture have to overcome market fluctuations so as to subsist stably and sustainably.

H8: Political supports for organizations/individuals newly participating in green supply chains have a positive impact on green supply chain's success (Political Supports). Political supports through policies enable supply chains to be carried out easier and on a larger scale. At the same time, Government supports also make it possible for the economy and the chain participants to promptly achieve success from green supply chains (Kamolkittiwong \& Phruksaphanrat, 2015).

H9: Participants' knowledgeable and experience have a positive impact on green supply chain's success (Knowledge \& Experience). This factor has a significant impact on the HR supply to the entire green supply chains and improves the chain performance and effectiveness throughout the operation process, from purchasing to distributing (Holt, 2009).

H10: The participation of other participants such as green architects, consultants and developers in supply chains has a positive impact on green supply chain's success (Actors Participation). That green supply chains in agriculture lack the participation of some other participants will keep the supply chains from making full use of the regional green resources, thus failing to create, use properly and achieve maximal performance (Sixiao, 2011).

H11: High costs of green supply chains have a negative impact on green supply chain's success (Costs). This is an issue that concerns all organizations, individuals when participating in supply chains. Initial investment costs necessary for the participation in green supply chains in agriculture as assessed are rather high, such as costs for green design, green manufacturing, green packing, etc. (Xianbing, 2011). High costs of chain application affect the decision to participate in supply chains of the relevant parties and restrict the expandability of supply chains in the market.

H12: Suppliers' inflexibility has a negative impact on green supply chain's success (Suppliers). Suppliers are not ready to participate in the process of applying new technology; this reduces the total chain performance 
(Tomohiro, 2011).

H13: Creativity logistics management has a positive impact on green supply chain's success (Logistics Management). Logistics has a major role in green supply chains in agriculture (Singh, 2012). Improper and uncreative use of transport services increases costs and exhaust fumes, thus affecting the environment and degrading the supply chain quality.

H14: Consumer awareness of green supply chains in agriculture and high-quality agricultural products has a positive impact on green supply chain's success (Consumer Awareness). This decreases the role of green supply chains in agriculture in the market and the supply chain expandability (Shreejith, 2012).

\section{Methodology}

The research gathered information from books, newspapers, magazines, domestic and international researches for studying the current situation of green supply chain application in Vietnam's agriculture and the factors affecting supply chain.

On the basis of literature review, the regression model with 14 independent variables was established to identify the factors affecting the green supply chain's success in Vietnam agriculture. Specifically:

$\mathrm{Y}=\mathrm{a}_{0}+\mathrm{a}_{1} \mathrm{x}_{1}+\ldots+\mathrm{a}_{14} \mathrm{x}_{14}+\varepsilon$

Where:

Y: the success of green supply chain in agriculture;

$a_{0}, a_{1}, \ldots, a_{12}, a_{13}, a_{14}$ : coefficients;

$\mathrm{x}_{1}, \ldots, \mathrm{x}_{12}, \mathrm{x}_{13}, \mathrm{x}_{14}$ : factors affecting green supply chain in agriculture, including 14 factors;

$\varepsilon$ : error term.

To test the model, we conducted a survey of the factors affecting the green supply chains in Vietnam agriculture. The survey participants are agricultural production and business firms, households in Vietnam participating in green supply chains. The questionnaire consists of two parts. Part 1 collects the information of the firms in green supply chains in agriculture. Part 2 collects the participants' the assessments of 14 factors affecting green supply chain in Vietnam agriculture by using a 1-5 point Likert scale. Our survey was conducted through Email on 216 key firms in the green agricultural chains in Vietnam, according to the list of firms accredited by NAFIQAD (National Agro-Forestry-Fisheries Quality Assurance Department), last updated in November 2016. There were 136 valid responses.

Table 1. Sample descriptions

\begin{tabular}{|c|c|c|c|c|c|}
\hline Criteria & Number & $\%$ & Criteria & Number & $\%$ \\
\hline Year of incorporation & 136 & 100 & Type & 136 & 100 \\
\hline$<1$ year & 46 & 33.82 & State-owned firm & 19 & 13.97 \\
\hline $1-3$ years & 32 & 23.53 & Joint-stock firm & 25 & 18.38 \\
\hline $3-5$ years & 33 & 24.26 & Co-operative & 18 & 13.24 \\
\hline $6-10$ years & 25 & 18.38 & Private firm & 49 & 36.03 \\
\hline Business scope & 136 & 100 & Limited liability firm & 25 & 18.38 \\
\hline Farming and animal husbandry & 32 & 23.53 & Labor number (person) & 136 & 100 \\
\hline Processing & 13 & 9.56 & Less than 100 & 28 & 20.59 \\
\hline Transport, storage \& logistics & 26 & 19.12 & $100-499$ & 55 & 40.44 \\
\hline Wholesaling agents & 17 & 12.50 & $500-999$ & 33 & 24.26 \\
\hline Retailing agents & 32 & 23.53 & $1.000-1.999$ & 20 & 14.71 \\
\hline \multirow[t]{6}{*}{ Export } & 16 & 11.76 & Revenue (billion) & 136 & 100 \\
\hline & & & Less than 1 & 9 & 6.62 \\
\hline & & & $1-10$ & 26 & 19.12 \\
\hline & & & More than $10-50$ & 47 & 34.56 \\
\hline & & & More than 50-100 & 35 & 25.74 \\
\hline & & & More than 100 & 19 & 13.97 \\
\hline
\end{tabular}

Around half of the firms in our survey have their rather short operational period (less than 1-3 years). This is the period firms come into operation. The participants in green supply chains in agriculture were mainly private firms, making up $36.03 \%$. In addition, the number of companies limited was considerably large $(36.76 \%)$. The survey participants were mainly farming, breeding firms $(23.53 \%)$, and retailing agents $(23.53 \%)$. The supply 
chain participants were medium-sized, with the strength of the workforce $100-499$, accounting for $40.44 \%$ of the firms under survey, and revenue over 10-50 billion dong accounting for $34.56 \%$. These figures indicate that medium-sized firms tend to participate in numerous green supply chains of agricultural products in order to improved product quality and its brand value.

\section{Research Results}

The regression results are shown in the table below. The model with dependent variables is the success of green supply chain and 14 independent variables are the factors affecting the success of green supply chains in agriculture. The $\mathrm{F}$ test achieved the reliability of $99 \%$ further indicates that the regression model is highly validated.

The adjusted R-squared value achieves 0.625 , indicates that the independent variables explain $62.50 \%$ of the variance of dependent variables. The multicollinearity test result of the model shows that all of VIF values are smaller than 4, thus ensuring that this phenomenon does not exist in the regression model. These results allow confirming that the regression model is highly validated.

Table 2. The results of the regression analysis

\begin{tabular}{|c|c|c|c|c|c|c|}
\hline & \multicolumn{2}{|c|}{ Unstandardized Coefficients } & \multirow{2}{*}{$\mathrm{t}$} & \multirow{2}{*}{ Sig. } & \multicolumn{2}{|c|}{ Collinearity Statistics } \\
\hline & $\mathrm{B}$ & Std. Error & & & Tolerance & VIF \\
\hline (Coefficient) & $-2.622 * *$ & 0.994 & -2.639 & 0.009 & & \\
\hline Firm Age & -0.012 & 0.064 & -0.186 & 0.853 & 0.807 & 1.238 \\
\hline Firm Size & -0.017 & 0.078 & -0.221 & 0.825 & 0.740 & 1.352 \\
\hline Annual Revenue & 0.101 & 0.072 & 1.404 & 0.163 & 0.656 & 1.524 \\
\hline Manager Commitment & $0.412 * * *$ & 0.076 & 5.395 & 0.000 & 0.558 & 1.794 \\
\hline IT System & -0.002 & 0.080 & -0.024 & 0.981 & 0.475 & 2.106 \\
\hline New Technology & $0.316^{* * *}$ & 0.073 & 4.313 & 0.000 & 0.555 & 1.803 \\
\hline Organizational Culture & 0.126 & 0.069 & 1.822 & 0.071 & 0.616 & 1.624 \\
\hline HR Quality & $0.292 * * *$ & 0.076 & 3.850 & 0.000 & 0.538 & 1.859 \\
\hline Energy \& Waste Management & -0.176 & 0.122 & -1.444 & 0.151 & 0.537 & 1.861 \\
\hline Market \& Competition & 0.002 & 0.087 & 0.027 & 0.978 & 0.383 & 2.608 \\
\hline Political Supports & 0.063 & 0.092 & 0.680 & 0.498 & 0.547 & 1.830 \\
\hline Knowledge \& Experience & $0.415^{* * *}$ & 0.112 & 3.703 & 0.000 & 0.497 & 2.013 \\
\hline Actors Participation & -0.079 & 0.100 & -0.795 & 0.428 & 0.488 & 2.048 \\
\hline Costs & 0.099 & 0.102 & 0.964 & 0.337 & 0.420 & 2.381 \\
\hline Suppliers & 0.044 & 0.104 & 0.427 & 0.670 & 0.522 & 1.917 \\
\hline Logistic Management & $0.229 *$ & 0.093 & 2.464 & 0.015 & 0.494 & 2.026 \\
\hline Consumer Awareness & $0.194 * *$ & 0.069 & 2.810 & 0.006 & 0.541 & 1.849 \\
\hline R 0.820 & \multicolumn{4}{|c|}{ Adjusted R Square 0.625} & & \\
\hline R Square 0.672 & \multicolumn{4}{|c|}{ Std. Error of the Estimate 0,7501} & & \\
\hline F 14.228 & \multicolumn{4}{|c|}{ Sig. 0.000} & & \\
\hline
\end{tabular}

Our regression results indicate eight factors not affecting agricultural chains in Vietnam, including: (i) IT system, (ii) organizational culture, (iii) energy \& waste management, (iv) market \& competition, (v) political supports, (vi) actors' participation, (vii) costs, and (viii) suppliers. In the context of Vietnam, these factors do not have significant impacts on the success of green supply chain in Vietnam agricultural firms.

According to our findings, there are six factors significantly affecting agricultural chain in Vietnam, including: (i) manager commitment, (ii) new technology, (iii) HR quality, (iv) knowledge \& experience, (v) logistics management, and (vi) consumer awareness, with the significance level of 99\%. Specifically:

The independent variable of Manager Commitment has significant and positive impacts on the green supply chain in agriculture $(\mathrm{B}=0.412 ; \mathrm{Sig} .=0.000)$. This indicates that hypothesis 1 is validated: the higher the manager commitment in the green supply chain, the higher the performance of green supply chains in agriculture is. This result is similar to the finding of Sunil (2010). Manager commitment in the green supply chain influences the total success, with the greatest impact on improving the green product quality and chain relationship. Currently, in Vietnam, most agricultural green supply chain managers are aware that supply chain management is a new method. Manager commitments, however, are still a few in numbers and do not yield high performance out of the limited knowledge, skills and professionalism of chain managers. Besides, green supply chains in agriculture are characterized by their reciprocal relationships which are expansive and not restricted to 
any firms. It is the requirement for integration and reciprocation among firms and the participants in other chains that restricts the performance of manager commitments (Minh Long, 2016).

New Technology has the B coefficient and Sig. value that are respectively 0.316 and 0.000 . This result confirms the better science and technology in agricultural supply chains are, the higher supply chain performance is, and vice versa. Our finding supports Kamolkittiwong \& Phruksaphanrat (2015)'s the research. The application of modern science and technology contributes to improving product quality, at the same time, reducing environmental impacts to a minimum, restrict hazardous substances and polluted waste affecting human health. According to a World Bank report on agricultural product supply chains (2016), Vietnam's mechanization indicator was 24.4/ 100 points, equivalent to that of Laos, Cambodia and Myanmar but below the Philippines (40 points). This result indicates that the application of new technology to green supply chains in Vietnam's agricultural sector is still limited, in most activities, from manufacturing, purchasing, processing and supplying to customers, rudimentary, obsolete technologies are still in use. It is this that reduces considerably the supply chain performance.

Our regression results also indicate that HR Quality as the independent variable has significant and positive impacts on the performance of green supply chains in agriculture $(B=0.292 ; \mathrm{Sig} .=0.000)$. This indicates that hypothesis 5 is accepted: the higher the HR quality is, the higher performance of green supply chains in agriculture is. Yu Lin et al. (2008) provided similar findings. Human resources' technical skills improvement through recruitment and training contributes to supply chains' success. However, a large number of Vietnam firms participating in agricultural chains, the quality of human resources is often weak due to the limitations in the HR recruitment and training. This results in the failure to bring the labor resource potential in the supply chains. By 2016, Vietnam had 13 universities and colleges offering agricultural-forestry training; $60 \%$ of vocational intermediates providing agricultural-forestry training. The number of graduates as bachelors, engineers, masters of the agricultural-forestry sector every year cannot meet the very rapidly growing demand in Vietnam. Especially, high-quality human resources cannot meet demand of supply chains. Obviously, human resources in green supply chains in agriculture at present are both insufficient and weak for agricultural production according to VietGap and GlobalGap standards (Truong Khac Tra, 2016).

Knowledge \& Experience as the independent variable has the B coefficient and Sig. values of 0.415 and 0.000 respectively. This result indicates that the hypothesis 9 is validated: the better the knowledge and experience of the participants in the supply chain are, the higher the success of agricultural supply chain is. This result consists with Holt (2009). Specifically, supply chain participants' knowledge and experience have impacts on HR supply to the entire chains and the chain performance throughout the process of operation, from purchasing to distribution. In other words, supply chain participants' knowledge and experience directly improve supply chain quality by improving workers' technical skills with policies on recruitment and training. Presently, the knowledge and experience of participants in green supply chains in Vietnam's agricultural sector are not high. Particularly, firms participating in supply chains - usually single and small-sized firms - offer low prices but lack criteria for controlling food quality, sanitation and safety, thereby often having higher extent of damage. In addition, out of their limited awareness of the hidden costs in some cost-saving activities, firms tend to choose sources of supply and logistics units at low price. This produces damage, contamination to agricultural products during transport process and shortens product lifespan (Nguyen Da Quyen, 2016).

With the $\mathrm{B}=0.229$ and Sig. $=0.015$, we can confirm that logistics management has significant and positive impacts on the performance of green supply chains in agriculture. So, the hypothesis 13 is validated. Singh (2012) provided similar results in his research. Specifically, creativity in transport and logistics management expedites chain activities. Appropriate transport services reduce costs and flue gases affecting the environment, from that to improve supply chain quality. A research conducted by The World Bank (2016) revealed that logistics management in green supply chains in Vietnam's agricultural sector currently was ineffective. The agricultural transport indicators of the Philippines and Laos were from 10-15 points higher than that of Vietnam. Furthermore, in the supply chain logistics of Vietnam, there are many purchasers, transporters and single and small-sized processing units. Such units often lack equipment, material facilities for operating green supply chains. Additionally, Vietnam falls into the group of countries with international transport activities not yet optimized. Although Vietnam's overall transport indicator has been assessed as being equivalent to that of Cambodia, Vietnam's international transport indicator equals half of Cambodia and the Philippines as well. It is the limitations above that reduce the performance of Vietnam's green supply chains in agriculture.

Consumer Awareness has significant and positive impacts on the performance of green supply chains in agriculture $(\mathrm{B}=0.194$; Sig. $=0.006)$. This shows that hypothesis 14 is also accepted: the higher the consumer awareness of green supply chains in agriculture is, the higher the performance of green supply chains in 
agriculture is. Our finding supports Shreejith (2012)'s the research result. High consumer awareness contributes to increasing the role of green supply chains in agriculture in the market and the implementation and expansion of supply chains. In fact, however, Vietnam consumers' the awareness of green supply chain and green agricultural products is still limited as they are in a "crisis" of confidence in domestic agricultural products. The cause of this is that Vietnam does not invest in trade promotion activities in the domestic market, attaches insufficient importance to the development of a professional distribution system and brand protection in agriculture. In addition, the official release of the VietGap standard system in 2008 gave an impulse to the program for clean, safe agricultural production in all the three domains of farming, breeding and aquaculture. However, Vietnam does not yet issue general brands in agriculture meeting VietGap standards. It is because of this the agricultural products that have met VietGap standards are being nearly equated, in terms of quality and safety, with those products not produced in accordance with the clean agricultural production process (The National Fishery Products Quality Management Service, 2011).

\section{Policy Implications}

From the research findings, we propose some recommendations for improving the green supply chains in Vietnam agriculture as follows:

\section{* For Vietnam firms in green supply chains in agriculture}

Firstly, Vietnam firms in green supply chains strengthen their interrelations through chain senior manager commitments or by improving manager capacity, knowledge. Further, the integration between chain participations should be improved by setting up a flexible, well-balanced transport system and proper logistics management to meet supply chain requirements.

Secondly, Vietnam firms should be proactive in planning, mobilizing capital to apply modern science and technology to production and business, towards developing clean products, without hazardous substances, safe for consumer health, and environmentally friendly.

Thirdly, Vietnam firms should improve chain participants' knowledge, experience by making suitable policies, regularly organizing vocational training courses for new workers. From that, firms can improve HR quality, establish close interpersonal relationships when participating in green supply chains in agriculture, and improve chain success.

Fourthly, Vietnam firms should intensify activities of promoting, introducing green supply chains in agriculture on the media, through meetings for exchange between firms and consumers, trade fairs, international conferences to increase the awareness of the role, supply chain performance by customers at home and abroad.

\section{* For Vietnam State}

Firstly, Vietnam State should intensify support for firms to renovate technology, receive new technology transfer from abroad to Vietnam, assist small-sized firms in increasing their production and business capacity. Governmental organizations, agencies should carry out programs for exchange, study and apply technology to production, to the system of green supply chains in agriculture between the firms newly participating and the successful firms in some supply chains.

Secondly, Vietnam State and local administrations should design vocational training courses for unskilled workers through training courses on clean agricultural production, technology application; exchange and learn from the experiences of countries with developed systems of green supply chains in agriculture, create models in accordance with international standards such as VietGab.

Thirdly, Vietnam State should take measures to manage, orient the development of green supply chains in agriculture and other fields as well in line with socioeconomic development orientation of the country. The state should create an operating environment for participants in green supply chains by increasing exchanges between supply chains, between firms participating in supply chains, between domestic and foreign firms. At the same time, State agencies should intensify propaganda about the effects of green supply chains in agriculture on the environment and on consumer health so as to increase the people's awareness.

Fourthly, Vietnam State should coordinate with banking systems to support with policies on loans for production, technology renovation of firms participating in green supply chains in agriculture to solve the operating cost problem of green supply chains in agriculture for firms participating in supply chains. From that, the development of green supply chains will lay firm groundwork for economic growth as a whole.

\section{Concluding Remarks}

The literature indicates 14 factors affecting green supply chains in agriculture including: (i) manager 
commitment, (ii) IT system, (iii) new technology, (iv) organizational culture, (v) HR quality, (vi) energy \& waste management, (vii) market \& competition, (viii) political supports, (ix) knowledge \& experience, (x) actors' participation, (xi) costs, (xii) suppliers, (xiii) logistics management, and (xiv) consumer awareness.

Our regression model with 14 independent variables was established to determine the factors affecting the success of green supply chains in Vietnam agriculture. We conducted a survey for identifying the factors affecting the success of green supply chains in Vietnam agriculture. The survey participants are agricultural production and business firms, and households in Vietnam participating in green supply chains. Our regression results indicate six factors significantly and positively affecting the green supply chains in Vietnam agriculture, namely: (i) manager commitment, (ii) new technology, (iii) HR quality, (iv) knowledge \& experience, (v) logistics management, and (vi) consumer awareness. On the basis of our findings, some recommendations are suggested to Vietnam firms in agricultural chains and the State for improving the performance of green supply chains in Vietnam agriculture in the coming time.

\section{References}

Bộ, N. P. N. (2016). Báo cáo tổng kết Công tác quản lý chất luợng vật tu nông nghiệp, an toàn thực phẩm năm 2016, kế hoạch trọng tâm 2017.

Dashore, K., \& Sohani, N. (2013). Green Supply Chain Management: A Hierarchical Framework for Barriers. International Journal of Engineering Trends and Technology (IJETT), 4(5).

Global Intelligence Alliance Group. (2009). Green Supply Chain Management in Asia-Pacific, 2009.

Holt, D. (2009). An Empirical Study of Green Supply Chain Management Practices Amongst UK Manufacturers. Journal of Manufacturing Technology Management, 20(7), 933-966. http://dx.doi.org/10.1108/17410380910984212.

Kamolkittiwong, A., \& Phruksaphanrat, B. (2015). An Analysis of Drivers Affecting Green Supply Chain Management Implementation in Electronics Industry in Thailand. Journal of Economics, Business and Management, 3(9). http://dx.doi.org/10.7763/JOEBM.2015.V3.299.

Lui, X. B. (2011). The Influence of Greening the Suppliers and Green Innovation on Environmental Performance and Competitive Advantage in Taiwan. Transportation Research Part E, 47, 822-836.

Minh, L. (2016). Chuỗi cung ứng nông sản thực phẩm an toàn là yêu cầu cấp thiết. CafeF, ngày 29/10/2016.

Mudgal, R. K., Shankar, R., Talib, P., \& Raj, T. (2010). Greening the supply chain practices: an Indian perspective of enablers' relationship. Journal of Advanced Operations Management, 1(2-3), 151-176. http://dx.doi.org/10.1504/IJAOM.2009.030671

Nguyễn, D. Q. (2016). Nông nghiệp Việt và những thách thức trong quản trị logistics. Thời báo Kinh tế Sài Gòn Online, ngày 30/9/2016.

Qu, S. X. (2011). Sustainable Production Practices and Determinant Factors of Green Supply Chain Management of Chinese Companies. Business Strategy and the Environment, 21, 1-16.

Sanjay, K. (2010). The study of knowledge transfer and green management performance in green supply chain management. African journal of Business Management, 4(1), 44-48.

Scupola, A. (2003). The adoption of internet commerce by SMEs in the South of Italy an environmental, technological and organizational perspective. Journal of Global Information Technology Management, 6(1), 52-71. http://dx.doi.org/10.1080/1097198X.2003.10856343

Shreejith, B. (2012). Examining Green Production and its Role within the Competitive Strategy of Manufacturing. Journal of Industrial Engineering and Management, 5(1), 53-87.

Singh, M. D. (2012). Modeling the Knowledge Sharing Barriers using an ISM Approach. International Conference on Information and Knowledge Management, 45, 233-238.

Sunil, L. (2011). Barriers to implement Green Supply Chain Management in automobile industry using Interpretive Structural Modeling (ISM) Technique-An Indian Perspective. Journal of Industrial Engineering and Management, 4(2), 231-257.

Tomohiro, S. (2011). Practices and Determinant Factors of Green Supply Chain Management of Chinese Companies. Business Strategy and the Environment, 21, 1-16.

Trương, K. T. (2016). Nhân lực ngành nông nghiệp: vừa thiếu vừa yếu. Diễn đàn Doanh nghiệp, ngày 
$21 / 07 / 2016$.

Yu, L. C., \& Hui, H. Y. (2008). An Empirical Study on Logistics services provider, intention to adopt Green Innovations. Journal of Technology, Management and Innovation, 3(1), 17-26.

\section{Copyrights}

Copyright for this article is retained by the author(s), with first publication rights granted to the journal.

This is an open-access article distributed under the terms and conditions of the Creative Commons Attribution license (http://creativecommons.org/licenses/by/4.0/). 